\title{
1.3. MANAGING INDUSTRY DEVELOPMENT FROM THE PERSPECTIVE OF BUILDING A LOGISTICS SUPPLY CHAIN
}

\begin{abstract}
Summary
The economic development of the country depends on economic development of the regions, which translates into increased pressure on companies from SME sector to raise its economic performance. Focusing on the industry, which dominates in the area, provides the opportunity to invest in it, what can result in improvement of its efficiency. The supporting solution of the local/regional development is the creation of clusters, which in the logistics solutions context provide a strong and organized group, forming a logistic supply chain. This paper presents a proposition for a cluster modelling in logistics perspective and in terms of regional management, also constituting promotion of local branches and the development of micro, small, and medium-sized enterprises in both production and logistics, which are instruments in creation process of the national economy.
\end{abstract}

Keywords: logistics supply chain, clusters, modelling

\section{Introduction}

Local development is seen as a whole of qualitative transformation of structure of the local area, concerning the status of its community life and functioning in its traders (Wojtasiewicz, 2005). The perception of local development in perspective e.g. strategic, creates the possibility to choose a scope that is creating problem, as well as focuses on issues determining the direction and dynamics of development of the territorial units. Entity performing governmental functions in a local development strategy is the basic level of local government (in Poland, function is performed by district or commune), which clarifies established and performs assumed actions. The object, in turn, are environmental needs of inhabitants, treated as a unit of local government, which binds to both potential resources and the economy in the spatial, ecological, social and economic approach (Kot, 2003). The purpose of local development strategies is their development itself, which in its intentions induces beneficial changes. Building competitive advantage is possible in perspective of finding an industry that can be regarded as dominant for the region. On the one hand, economic globalization absorbs its volume of companies in the SME sector and makes them have limited financial resources in its creation. On the other hand, statistics show a significant share of these companies in the creation of national economies. This raises the contradiction of economic signals from the perspective of the economy and the participating entities. Economic aspirations of the European Union assume a 
certain unity in this field, hence Polish "market" should seek to unify chosen industrial sectors. The aim of such a consolidation would be to create a few/over a dozen projects that allow one to compete in foreign markets. This solution is possible through the use of resources from the European Fund for the period 2014-2020 arising from the Europe 2020 strategy (more www.funduszeeuropejskie.gov.pl). Objectives of the project relate to investments in enhancing competitiveness and innovation development of the national economy. The project can be positively achieved by assuming the connection of the clusters with the same or related industries and then to build e.g. a logistic supply chain. This will allow to use e.g. raw materials, specialized and skilled workforce or even local capacity to strengthen the regional economy. As a result, different areas of the country could generate strong economic regions that would have the opportunity to compete in, and with foreign markets.

\section{Local and regional development - strategic perspective}

Building networks in combining clusters and logistic supply chains requires the determination of a strategy. It is an essential element of the whole process because it is important to define the objectives at all levels of strategic management. The strategic perspective must be also integrated into the area strategy and therefore consistent with the strategy of the region.

The construction process of local development strategies is perceived from the perspective of: vision, an entrepreneurial culture and the spatial order.

Local development strategy can fulfil several basic functions which include (Strzelecki, 2008):

- activation function, starts and activates the team and group thinking on development, conceptual problems, related to the future of the local system;

- concentration function, focuses on the most important problems of the local unit from the standpoint of maximum use of municipal resources;

- orientation function, depends on the orientation of any local activity following in the direction of implementation adopted strategy, vision and goals;

- coherence function, provides opportunities to harmonize, mitigate and eliminate tensions in relations with members of the local community;

- flexibility function, allows one to develop skills that apply to present identification and elimination of undesirable factors that may occur in the near future.

Another advantage of building and implementing a local strategy - besides the local development - is its role in positioning, which strengthens the participation of local entrepreneurs in a competitive market. Regional development strategy in the literature is defined as the determinant of social and economic changes. On one hand, the strategy gives the development objectives, on the other, it is an environment (concentration of factors and entities) that holds resources, tools, instruments and mechanisms that implement these goals. Development of the region depends on the directions and actions taken in the process of strategic decisions (Ślusarz, 2006). 
Planning is a form of creation of a regional development strategy, which sets out the principles of the regional structure. Its desirability is developing benefits - developing strategic goals - by the strategy entity that simultaneously have its impact on the subject of development strategies. The benefits of the desirability of the strategy come down to principles of regional development policy, as well as activities, resources, procedures, and techniques of strategic planning (Ślusarz, 2006). The process of constructing a regional development strategy has a dimension of decision and time, and involves several steps (Wiatrak, 2006). The six steps of this process are illustrated by Figure 1.

Figure 1: Process of constructing regional development strategy

- Input assumptions: describe the determinants of the region
STEP 1 development at a time

Source: own elaboration based on Wiatrak (2006)

The whole creation process also includes coordination activities, which should be linked with the continuing development activities, taking place in other sectors of the local economy, thus inducing social recognition in the field of strategic regional changes. 
Sałek, R. - Wiśniewska-Sałek, A.

\section{Cluster mapping process as an element of modeling the dominant industry}

Success in clustering process is dependent on several key elements that exist in the economy. What is important is the appropriate combination thereof in a particular area where the controlled participation and competition bring benefits. Impulses to take certain steps aimed to join the cluster are e.g.: the knowledge transfer, innovation, labour market and employment, market access, competition, entry barriers in the logistic chain, business services, and infrastructure.

Knowledge transfer is one of the main factors leading to the agglomeration of companies; its basic principle is to search for the company's external sources of knowledge whereas proximity resulting from being in the agglomeration significantly facilitates the exchange of knowledge between companies. This rule also applies to relations of companies with universities or research institutes. Geographical concentration of enterprises is partly generated by people, or more precisely by their need for innovation and knowledge management, which have a solid foundation of mutual trust and understanding (Isaksen, 2004).

Innovation is an important element in creating a competitive advantage. The process of its creation depends to a large extent on the knowledge, ideas, and contribution to society as a whole. In this sense, the company's innovation is strongly dependent on its access to external knowledge and to correlate it with the appropriate external entities that possess it. The geographical concentration of the cluster plays an important role in the process of continuous improvement and innovation, creating a close relationship between innovation and competition of enterprises. Companies located close to each other are much more dynamic competitors, looking for innovation, because they are constantly subjected to pressure and comparisons. In addition, universities located around the industry have a better idea of their needs and are able to take appropriate action, in a manner that reflects the vendors who regularly work with R\&D department (Porter, 1998).

Labour market, increasing specialization between enterprises and the distribution of work in the individual processes can lead to achieve economies of scale, which in turn is a generator in building a competitive advantage in the cluster. This solution seems to be very beneficial for small companies because it allows the operation benefits both for themselves and for large companies. Cluster can start a self-perpetuating growth; then the scale will require the division of labour and expertise cooperating entities, which leads to a specialization of labour market, more technologically advanced product, and demand growth (Sternberg and Litzenberger 2004).

Competition plays a very important role in the activities undertaken within the cluster. Local market and pressures associated with the action on it, affects managers in a motivating way as they try to outdo each other regarding image and reputation (Isaksen, 2004).

Performing the mapping process that is used to verify the validity initiation of cluster initiative, allowing you to handle it in process of modelling the dominant industry (Figure 2.). 
Figure 2: Stages of procedure in the clusters identification

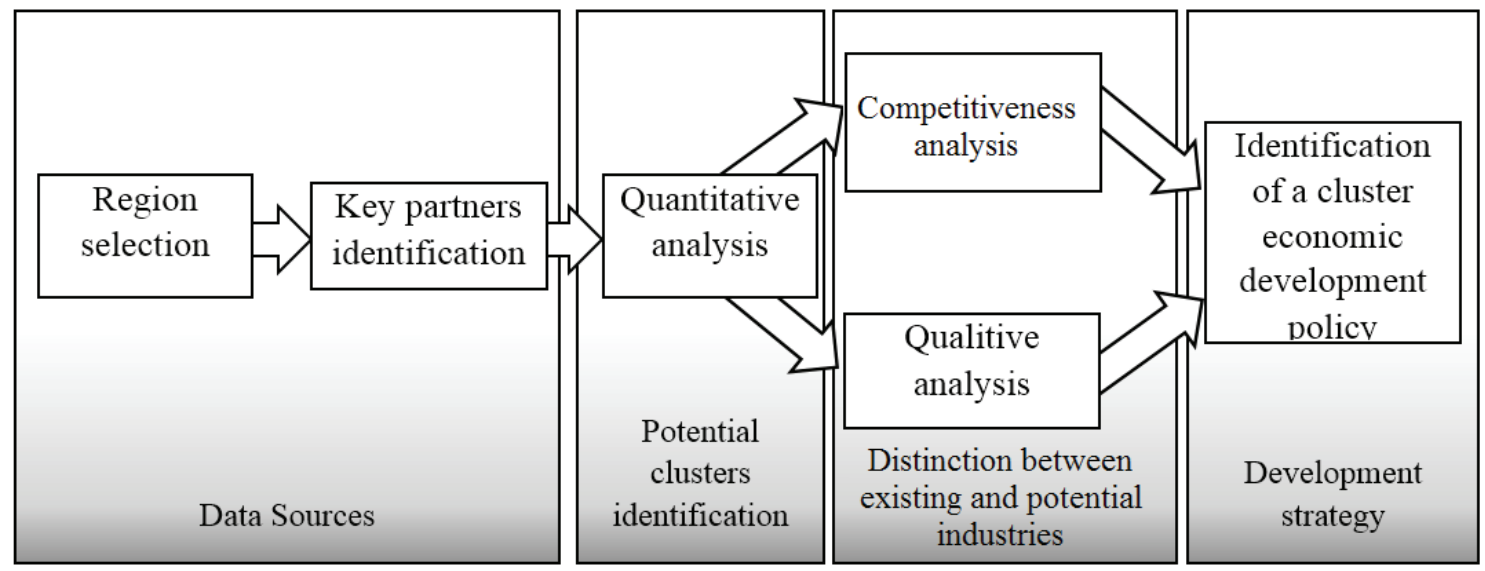

Source: Skawińska, Zalewski. (2009), p. 189

The subsequent stages presented in the figure above are related in their activities to the following stages:

- Stage I: Region selection - it is used to identify regions which may constitute the reference point for the next cluster initiatives;

- Stage II: key partners identification - involves an examination of entrepreneurs number (in terms of their statistical conditions in a particular area) involved in the clusters merger, as well as institutions and entities that are participants in a building common cluster;

- Stage III: Quantitative analysis - involves performing calculations using i.e. the location factor (e.g. Florence'a), the rank of specialization or location factor, determination of the force concentration entities (e.g. Ellison and Glaeser agglomeration index) and the opportunity to create a cluster based on clustering index;

- Stage IV: Qualitative analysis - is based on a subjective assessment made by the respondents;

- Stage V: Competitiveness analysis - it allows to explore the external environment of a cluster, which will identify the hazards that may interfere with cooperation undertaken within working in networks. They have their source in the projects of other industries or clusters neighbouring with the same profile;

- Step VI: Identification of a cluster economic development - the determination, by the cluster members, of a common mission, policy and activities level that create a cluster strategy. The last step allows one to fasten the entire undertaking in a single project by defining an appropriate strategy. This is the most important part of the whole process of building a dominant industry due to the number of actors and the scale of operations.

Building the domestic industry in conjunction with the logistic supply chain requires clarification of a coherent strategy, which will allow determining the instruments to build a large project. 
Sałek, R. - Wiśniewska-Sałek, A.

\section{Logistics approach to the dominant industry in the strategic perspective}

Leading business activity in a global environment requires participation in a dynamic and spontaneous process, and it is associated with a flexible "international life" (Luoma, 2006) and the adaptation ability. Transport processes characterized by high consistency, being integrated with each other are crucial for the international and domestic supply chains (Skibińska, 2013). The intensity of the internationalization process does not have a single character, but an important issue in the field of international management. The expansion creates opportunities for determining the rate of growth, but also plays an important role as a tool to improve strategic management in the enterprise. The presence of internationalization, globalization, regionalization, and integration in the socio - political - economic area is largely the effect of functioning of companies and groups of people, where the broad internationalization processes involve different business areas (Becker - Freeman 2006). The choice of strategy depends on evaluation of the competitive relationship between the downward pressure on costs and matching offers to local markets (Godet 2000). Maintaining a competitive advantage on a global scale requires improving the effectiveness through its optimum relationship between global integration and the efficient undertaking of actions, and their local adaptation. The choice of the strategy with the parameters describing the particular market in which the company prospers (Szymczak, 2005).

There are the following four main types of cross-border corporate strategies.

Transnational strategy is the most difficult and the most advanced tactic, which requires both developed resources and skills (Pierścionek, 2011).

Multinational strategy is a strategy with intensive pressure on matching production and sales to local domestic markets, combined with weak impact on costs in countries where foreign affiliates are located (Olszewska, 2001).

Global strategy implements projects aimed to compete all over the world, where they support large segments of customers with standard needs. There are very low costs at the level of this strategy, as well as an excellent technological standard of the product constituting the foundation of a competitive global enterprise (Romanowska 2004).

International strategy is characterized by a low pressure on the local market adaptation and low costs, so taking this kind of strategy is most often the first step in the internationalization of a company. The strategy has a high degree of centralization operational and strategic decisions (Pierścionek, 2011).

The choice of a strategy type is dependent on the size of the company and its position in domestic market, but also depends on the opportunities that may affect the development of the company. Companies' strategies in the internationalization process are also largely dependent on logistics, which is a scientific field present in all matters related to aspects of enterprise management (see more Nowakowska-Grunt, 2007) and marketing, that is a component of business ventures. 
Table 1: External conditions and directions of a strategy in terms of logistics

\begin{tabular}{|c|c|c|c|c|}
\hline & Global strategy & $\begin{array}{c}\text { International } \\
\text { strategy }\end{array}$ & $\begin{array}{c}\text { Multinational } \\
\text { strategy }\end{array}$ & Transnational strategy \\
\hline نِ & $\begin{array}{l}\text { The same } \\
\text { preferences for } \\
\text { logistical support } \\
\text { in individual } \\
\text { markets, equal } \\
\text { service } \\
\text { opportunities }\end{array}$ & $\begin{array}{l}\text { In a large range } \\
\text { similar preferences } \\
\text { for logistical } \\
\text { support, similar } \\
\text { service capabilities }\end{array}$ & $\begin{array}{l}\text { Different } \\
\text { preferences for } \\
\text { logistical } \\
\text { support and / or } \\
\text { different service } \\
\text { capabilities }\end{array}$ & $\begin{array}{l}\text { Different preferences } \\
\text { about the certain } \\
\text { elements of logistic } \\
\text { services and/or different } \\
\text { implementation } \\
\text { possibilities of some } \\
\text { logistic processes }\end{array}$ \\
\hline & $\begin{array}{l}\text { Standard } \\
\text { (homogeneous) } \\
\text { logistic market } \\
\text { services, } \\
\text { performed } \\
\text { globally }\end{array}$ & $\begin{array}{l}\text { Logistic service with } \\
\text { a predominance of } \\
\text { standard } \\
\text { components, realized } \\
\text { in a distinct manner } \\
\text { on individual } \\
\text { markets }\end{array}$ & $\begin{array}{l}\text { Localized, } \\
\text { adapted to any } \\
\text { market, distinct } \\
\text { logistic service }\end{array}$ & $\begin{array}{l}\text { Logistic service realized } \\
\text { on the basis for } \\
\text { combination of standard } \\
\text { and diverse elements }\end{array}$ \\
\hline
\end{tabular}

Source: Szymczak (2005), p. 224

Presented in the table above circumstances and trends of logistics in the individual strategies of companies internationalization indicate the place where the course of logistic action can support the process of operational effectiveness. The competence of logistics in the company on the international market may include foreign trade, cooperation with foreign co-operator, or independent international activity (Ciesielski, 2001).

The individual construction elements of the logistic supply chain in terms of the dominant industry should be based on its assumptions on the specific strategy of internationalization. Logistic supply chain should be of global coverage but should exploit the national potential.

\section{Conclusions}

Working on the cluster mapping is a very important procedure from the standpoint of its creation and regional development, while modelling of the dominant industry is an important procedure in terms of its significance for the development of the national economy. Identifying next steps and their precise analysis will allow companies to prepare for the implementation of new solutions.

Building a national economy determines the strength of state in foreign markets. It is very important that the country has at least a few industries that will use their own resources to reduce production costs by government funding of internal operations. The pro-national proceedings in the economic and ecological field will condition the social support. Therefore, the strength of the country will increase stabilizing its position in foreign markets. 
Sałek, R. - Wiśniewska-Sałek, A.

Actions pursuing to build projects on a national scale require good preparation and organization; it is necessary to establish some common strategy that will be compatible with the logistics capabilities of the country, also in the field of its infrastructure.

\section{References}

1. Becker W.M., Freeman V. (2006): Going from global trends to corporate strategy, The McKinsey Quarterly No 3.

2. Ciesielski M., (2001): 'Globalizacyjna a logistyczne aspekty konkurencyjności' in TRANS'01-Wspólna Europa. Przedsiębiorstwa wobec globalizacji eds. H. Brdulak, \& T. Gołębiowski, PWE Warszawa, p. 135.

3. European Communities, (2002): High-tech SMEs in Europe, No. 6, Office for Official Publications of the European Communities, Luxembourg.

4. Godet M., (2000): The art of scenarios and strategic planning: tools and pitfalls, $\begin{array}{lllll}\text { Technological Forecasting Social Change Vol. } & 65 .\end{array}$ http://dx.doi.org/10.1016/S0040-1625(99)00120-1

5. Isaksen A., (2004): Knowledge-based Clusters and Urban Location: The Clustering of Software Consultancy in Oslo, Urban Studies 41, 5/6. http://dx.doi.org/10.1080/00420980410001675797

6. Kot J., (2003): Zarządzanie rozwojem gmin a praktyka planowania strategicznego, Wyd. UE Łódź.

7. Luoma M., (2006): A play in four arenas: How complexity can serve management

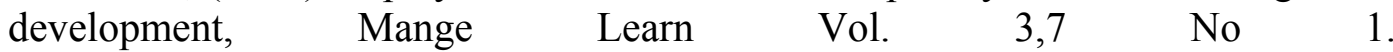
http://dx.doi.org/10.1177/1350507606058136

8. Nowakowska-Grunt J. (sc. ed.), (2007): Ekonomiczne i techniczne aspekty zarządzania przedsiębiorstwem, Wyd. WZPCzęst., Częstochowa.

9. Nowakowska-Grunt J., (2010): Ryzyko w strategiach logistycznych przedsiębiorstw międzynarodowych, Zesz. Nauk.UE Pozn. No. 157, Poznań.

10. Olszewska B., (2001): Współczesne uwarunkowania zarządzania strategicznego przedsiębiorstwem. Wybrane zagadnienia, Wyd. AE im Oskara Langego, Wrocław.

11. Pierścionek Z., (2011): Zarządzanie strategiczne w przedsiębiorstwie, PWE, Warszawa

12. Porter M.E., (1998): Clusters and the New Economics of Competition, Harvard Business Review 76, no. 6, Boston.

13. Romanowska M., (2004): Planowanie strategiczne w przedsiębiorstwie, PWE, Warszawa.

14. Skawińska E., Zalewski R.I. (2009): Klastry biznesowe w rozwoju konkurencyjności i innowacyjności regionów, Świat-Europa-Polska, PWE Warszawa.

15. Skibińska W. (2013): Dynamics of transportation development as a basis for the development of logistics in Poland, Polish Journal of Management Studies Vol. 7, p. 290-298. 
16. Sternberg R., Litzenberger T., (2004): Regional Clusters in Germany-their Geography and their Relevance for Entrepreneurial Activities, European Planning Studies, Vol. 12/6. http://dx.doi.org/10.1080/0965431042000251855

17. Strzelecki Z., (2008): Gospodarka regionalna i lokalna, PWN Warszawa.

18. Szymczak M., (2005): 'Logistyka w strategiach ekspansji międzynarodowej firm' in Logistyka $w$ internacjonalizacji przedsiębiorstw Unii Europejskiej eds. Gołembska E., Wyd. AE Poznań.

19. Ślusarz G., (2006): Zarządzanie rozwojem przez jednostki samorządu terytorialnego - specyfika, potrzeby i wyzwania, Problemy Zarządzania, nr 3(13).

20. Wiatrak A., (2006): Skała regionalna i lokalna - istota, rozwój i zarządzanie, Problemy Zarządzania, nr. 3(13).

21. Wojtasiewicz L., (2005): 'Problemy rozwoju lokalnego w aktualnej polityce gospodarczej' in Polityka gospodarcza. Studia i przyczynki eds. Trajkowski J., Garmond Oficyna Wydaw. Poznań

22. www.funduszeeuropejskie.gov.p1/2014_2020/Strony/RMprzyjalprojektydokument ownanowaperspektywe_08012013.aspx 